\title{
Financial Statement Ratio Analysis to Assess Financial Performance at PT Poly- chem Indonesia Tbk
}

\author{
Rahmah Hasanah*, Fitri Mareta, Heliani, Amalia Rabiatul Adawiyah, Erika Krismonica \\ Nusa Putra University, West Java, Indonesia
}

*Corresponding author:

E-mail: rahmah.ha-

sanah_ak19@nusaputra.ac.id

\begin{abstract}
The purpose of this study is to determine the financial performance of PT. Polychem Indonesia Tbk using financial ratio analysis from 2017 to 2019. The financial ratios analyzed are Current Ratio (CR), Quick Ratio (QR), Debt Ratio (DR), Debt to Equity Ratio (DER), Gross Profit Margin (GPM), Net Profit Margin (NPM), Return on Investment (ROI) and Return on Equity (ROE). The data in this study uses data in the 2017-2019 financial statements. The data analysis method used is the horizontal analysis method, which is useful for comparing financial reports in certain years. From the data analysis, it can be seen that the liquidity ratio of PT. Polychem Indonesia Tbk seen from the average CR and QR in the last 3 years was $336.5 \%$ and $184.1 \%$. This proves that the current ratio and a quick ratio of PT. Polychem Indonesia Tbk is in good condition. The solvency ratio of PT. Polychem Indonesia Tbk is seen from the average DR and DER of PT. Polychem Indonesia Tbk in the last 3 years amounted to $22.6 \%$ and $33.1 \%$. This condition shows the debt ratio and debt to equity ratio of PT. Polychem Indonesia Tbk is in good condition. Profitability ratio of PT. Polychem Indonesia Tbk seen from the Average Gross Profit Margin (GPM), Net Profit Margin (NPM), Return on Investment (ROI) and Return on Equity (ROE) in the last 3 years each was $0.0 \%,-5,3 \%,-4.8 \%$ and $-6.1 \%$ are in poor condition because they are below the industry standard.
\end{abstract}

Keywords: Financial ratios, liquidity ratios, solvency ratios, profitability ratios

\section{Introduction}

In this era of globalization, technology is changing very rapidly. Many investors invest in various companies. In this era, information is now easy to get quickly. With the conditions, there are many benefits for the business world. Especially companies that have gone public. In general, many companies have advantages in terms of competing with one company with another company, with these advantages, companies can be able to maintain existing performance within the company. Because good financial performance allows the company to keep its finance. This could be a factor in the company's benchmark.

The definition of financial performance is the determination of certain measures that can measure the success of an organization or company in generating profits. Meanwhile, according to IAI (2007), Financial Performance is a company's ability to manage and control its resources. In general, the financial performance of a company is a description of the financial condition of a company. So that we can assess and measure finances, one of which is by looking at the financial statements of the company first. And to measure financial performance we can use financial ratios.

Financial ratios are a financial analysis tool for companies in assessing the company's performance based on the comparison of financial data in financial reports, such as balance sheets, cash flow reports, and income statements. With financial ratios, company management, investors, and creditors will find it easier to analyze business performance, find out the points of trouble, finances, and financial weaknesses of the company, and make it easier to make decisions.

\section{How to cite:}

Hasanah, R., Heliani, F. M., Adawiyah, A. R., \& Krismonica, E. (2021). Financial statement ratio analysis to assess financial performance at PT Polychem Indonesia Tbk $1^{\text {st }}$ ICEMAC 2020: International Conference on Economics, Management, and Accounting. NST Proceedings. pages 40-47. doi: 10.11594/ nstp.2021.1004 
PT Polychem Indonesia Tbk is a company originating from Indonesia which is engaged in the manufacture of petrochemicals and polyester. The company has two divisions, namely the polyester and chemicals business. In the share information of PT Polychem Indonesia Tbk as a company that has been an issuer for more than 20 years. The company has fairly competitive performance. This can be seen from the placement of the Company's shares listing board by the Indonesia Stock Exchange, from the development board to the mainboard, effective as of 30 May 2014.

At the annual general meeting of shareholders (AGMS) Polychem Indonesia Tbk (ADMG) agreed not to distribute dividends from the 2018 financial year profit. "(Because) suffered losses, so we cannot distribute dividends," said PT Polychem Indonesia Tbk Corporate Secretary, Chandra Tjong. in a public presentation at the Hotel Ayana Midplaza, Tuesday (25/6). Throughout 2018 the company's sales were indeed better than in 2017. However, ADMG still recorded a loss (Intan, 2019). So on that statement, we want to examine further, why the company may suffer losses

\section{Literature Review}

Indonesian international labor migration gives a huge contribution to the lives of many migrant workers, their families, and also the Indonesian economy. More than 9 million Indonesian citizens are working abroad, of almost 7\% of the total Indonesian workforce (World Bank, 2017). Remittance is a portion of the salary or income of Indonesian Workers (TKI) sent from abroad to their families in the country. Remittances have a positive impact on increasing financial inclusion, some studies reveal remittances as part of a form of transfer as an inclusive financial entry point (Bank Indonesia, 2019).

Studies on the impact of PMA and remittances on the economies of developing countries still produce different findings. As empirical research found a positive impact of FDI inflows on economic growth (Borensztein et al., 1998; Koko, 2006; Johnson, 2006). While others see that the impact of PMA on economic growth is insignificant (De Mello, 1999; Ali \& Mingque, 2008) or even negative (Alfaro, et al., 2004). The same thing occurs in the study of remittances where some argued that remittances could drive economic growth (Giuliano \& Ruiz-Arranz, 2009; Beck \& Hassan, 2009; Chami et al., 2005; Lipton, 1980).

Issahaku \& Amidu (2018) examined two hypotheses related to remittance and economic growth about the quality of domestic institutions. The findings show that countries with poor domestic institutions will 'import' growth by attracting more remittances because their institutions are unable to support growth in other ways. Meanwhile, countries with weak domestic institutions will be more efficient and careful in utilizing remittances because their institutions are more likely to fail to manage remittances. In other words, the impact of remittances on a country's economic growth will be influenced by the country's capacity to absorb the remittance flows they receive (Bettin \& Zazzaro, 2011).

Nwaogu \& Ryan (2015) also carried out research related to the impact of foreign investment (PMA), foreign aid, and remittances on economic growth in 53 African countries and 34 Latin American and Caribbean countries. The previous studies have produced different findings regarding the impact of FDI, foreign aid, and remittances on economic growth and development. Some find that these factors have a positive effect (Chenery \& Strout, 1966; Burnside \& Dollar, 2000; Lumbila \& Kevin, 2005) while others find them to have a negative or no impact at all (Chami et al., 2005; Mah, 2010). The explanation generally given is that the impact of each of these factors is influenced by condition variables or institutions. For example, FDI is found to increase economic growth only if the FDI provides access to foreign technology (Lyroud et al., 2004); foreign aid can have a positive impact depending on how much financial liberalization is in the recipient country (Ang, 2010); remittances can have positive effects only if they are used for productive activities - not consumptive (Ekanayake \& Halkides, 2008).

Other researches about remittance were conducted by Carment \& Calleha (2018) to explain the benefit of remittance by looking further at the role of the diaspora in the context of a fragile nation. Diasporas are generally well-known 'agents of change' for development. This understanding is based on the assumption that the global market regime has failed to ensure an equal distribution of wealth among countries in the world. In such a context, a diaspora that is not seen by the interests of the international regime and motivated by a love of the country of origin is considered capable of mobilizing resources 
(remittances) from developed countries to rapu countries (Koinova, 2012). Related to this case, researchers on diaspora remittances generally agree that remittances will only have a positive impact on economic growth if used for investment, not for consumption (Debass \& Ardovino, 2009).

\section{Methodology}

\section{Definition of financial statements}

The financial statements of each company are made to provide useful information for report users, financial reports can be used as a reference for consideration when in the decision-making process. The financial statements are the result of an accounting process that can be used as a tool to communicate financial data or company activities to interested parties.

According to the Financial Accounting Standards, PSAK No.1 financial reports are periodic reports that are prepared according to generally accepted accounting principles.

regarding the financial status of an individual, association, or business organization consisting of balance sheets, income statements, changes in equity, cash flow statements, and notes to financial statements.

Financial reports have a very important function in the capital market in a company, namely to provide information that can describe the company's performance. In the financial statements, there are also company activities in a certain period. These activities are then translated into currency values, both in rupiah and in foreign currencies.

\section{Purpose of financial statements}

The purpose of financial statements is to provide information on the financial position, financial performance, and cash flow of the entity that is useful for users of financial statements in making economic decisions. To achieve this objective, financial statements provide information about the entity which includes: (a) assets, (b) Liabilities, (c) Equity, (d) Income and expenses, including gains and losses (e) contributions from and distributions to owners in the capacity as owner of (f) cash flow.

According to the Financial Accounting Standards the objectives of financial statements are:

1. Provides information about the company's financial position, performance, and changes in the company's financial position that is useful for a large number of users in making economic decisions.

2. The financial statements that are prepared aim to meet the needs of the users of financial statements. However, financial statements do not provide all the information that users may need in making economic decisions because they reflect financial effects and past events.

3. Financial statements show what management has done or is responsible for the resources entrusted to it

\section{Financial statement analysis}

Financial statement analysis here has two meanings, namely financial analysis and reporting. To explain the meaning of this word, we can explain it from the meaning of each word. The word analysis is breaking or decomposing a unit into various smallest units. While the financial statements are the balance sheet, profit/loss, and cash flow (funds). When these two meanings are combined, financial statement analysis means: "decomposing financial statement items into smaller units of information and seeing the relationship that is significant or has meaning between one another, both quantitative data and non-quantitative data with the aim of to know deeper financial conditions which are very important in the process of making the right decisions.

\section{Definition of financial ratios}

The financial ratios are "The activity of comparing numbers in the financial statements. Comparisons can be made between one component by component with one financial report or between components that exist between financial statements. Then the figures being compared can be figures in one period or several periods. 
The financial ratios are figures obtained from the results of comparisons of one financial statement account with other accounts that have a relevant and significant relationship.

Financial ratios have the meaning of comparing financial figures from one period to the next to see whether the company's financial condition has increased or not.

\section{Methodology}

\section{The scope of research}

This research was conducted to analyze the company's financial performance using a financial ratio method and EVA at PT Polychem Indonesia Tbk, which is a state-owned company (BUMN). This company is engaged in textiles. The data taken for this research are from 2017 to 2019.

Data source

The data used in this study uses secondary data in the form of financial report documents from 2017 to 2019 obtained from the Indonesia Stock Exchange or IDX and PT Polychem Indonesia Tbk and is equipped with a library study.

Analysis model

This study uses a horizontal comparison method and a qualitative method for the financial statements of companies that suffer losses. The states that the horizontal method is to compare financial statements in several periods. Horizontal analysis compares two financial reports, namely the current financial report and the previous year's financial report which is used as the basis. Horizontal analysis can be three or more comparative reporting periods. From the results of this analysis to see how financial reports have increased or decreased from one period to the next. As for assessing the performance of these financial statements using the following analysis tools:

1. Financial Ratio Analysis

a. Liquidity Ratio

The liquidity ratio is a ratio that measures the ability of how liquid the finances of a company are or how the company can pay if the company goes bankrupt or the company can pay the short-term debt. in this ratio, there are two ratios to be calculated.

- Current Ratio

- Quick Ratio

b. Solvency Ratio

The solvency ratio is almost the same as the liquidity ratio. What distinguishes this ratio is that it measures a company's ability to pay the short-term and long-term debt.

- Debt Ratio

- Debt to Equity Ratio

c. Profitability Ratio

The profitability ratio is the ratio to gain profit or profit within a company.

- Return on Investment (ROI)

- Return on Equity (ROE)

- GPM

- NPM

\section{Results and Discussion}

Analysis of the financial performance of PT Polychem Indonesia Tbk using financial ratios and economic value added (EVA). The financial ratios used are liquidity ratios, solvency ratios, and profitability ratios. Liquidity ratio using current ratio and fast ratio. The solvency ratio uses the ratio of debt and the ratio of debt to equity. Profitability ratios use return on investment, return on equity, GPM, and NPM.

The liquidity ratio at PT Polychem Indonesia Tbk is as in the following table 1. 
Table 1. Current ratio PT Polychem Indonesia Tbk 2017 - 2019 (expressed in USD)

\begin{tabular}{lccc}
\hline \multicolumn{1}{c}{ Explan } & \multicolumn{3}{c}{ Year } \\
& 2017 & 2018 & 2019 \\
\hline Current Assets & 149.564 .786 & 124.180 .421 & 110.385 .770 \\
Current Liabilities & 69.487 .329 & 26.463 .482 & 33.969 .979 \\
Current Ratio & $215,2 \%$ & $469,3 \%$ & $325,0 \%$ \\
\hline
\end{tabular}

Source: $w$ ww.idx.co.id

From the table above it can be explained that the current ratio of PT. Polychem Indonesia Tbk in 2017 amounted to $215.2 \%$. In 2018. there was an increase of $469.3 \%$ and in 2019 it decreased again by $325.0 \%$. Next will be analyzed the company's quick ratio. As for the quick ratio of PT. Polychem Indonesia Tbk is shown in the following table 2.

Table 2. Quick Ratio PT Polychem Indonesia Tbk 2017 - 2019 (expressed in USD)

\begin{tabular}{lcrr}
\hline \multicolumn{1}{c}{ Explan } & 2017 & \multicolumn{3}{c}{ year } & \multicolumn{1}{c}{2019} \\
\hline Current Asset & 149.564 .786 & 124.180 .421 & 110.385 .770 \\
Inventories & 61.916 .793 & 56.746 .999 & 52.145 .310 \\
Current Liabilities & 69.487 .329 & 26.463 .482 & 33.969 .979 \\
Quick Ratio & $126,1 \%$ & $254,8 \%$ & $171,4 \%$ \\
\hline
\end{tabular}

Source: $\underline{w w w . i d x . c o . i d}$

From the table above, it can be explained that the quick ratio of PT Polychem Indonesia Tbk in 2017 was $126.1 \%$. In 2018, it increased by $254.8 \%$ and in 2019 it experienced a decline of $171.4 \%$ again. Next will be analyzed the company's solvency ratio. The solvency ratio of PT. Polychem Indonesia Tbk is shown in the following table 3 .

Table 3. Debt Ratio PT Polychem Indonesia Tbk 2017 - 2019 (expressed in USD)

\begin{tabular}{lccc}
\multicolumn{1}{c}{ Ket } & 2017 & Year & 2019 \\
\hline Total Liabilities & 134.518 .424 & 36.903 .892 & 47.404 .827 \\
Total Assets & 374.110 .303 & 280.679 .854 & 255.228 .195 \\
Debt Ratio & $36,0 \%$ & $13,1 \%$ & $18,6 \%$ \\
\hline
\end{tabular}

Source: $\underline{w w w . i d x . c o . i d}$

From the table above, it can be explained that the Debt Ratio of PT. Polychem Indonesia Tbk in 2017 amounted to $36.0 \%$. In 2018, it decreased by $13.1 \%$ and again increased in 2019, name-ly by $18.6 \%$. Next will be analyzed the company's Debt to Equity Ratio. As for the Debt to equity ratio of PT. Polychem Indonesia Tbk is shown in the following table 4.

From the table above, it can be explained that the Debt Ratio of PT. Polychem Indonesia Tbk in 2017.

Table 4. Debt to equity ratio PT Polychem Indonesia Tbk 2017 - 2019 (expressed in USD)

\begin{tabular}{|c|c|c|c|}
\hline Explan & $\begin{array}{l}\text { Year } \\
2017\end{array}$ & 2018 & 2019 \\
\hline Total Debt & 134.518 .424 & 36.903 .892 & 47.404 .827 \\
\hline Total Capital & 239.591 .879 & 243.775 .962 & 207.823 .368 \\
\hline DER & $56,1 \%$ & $15,1 \%$ & $22,8 \%$ \\
\hline
\end{tabular}

Source: www.idx.co.id 
From the table above, it can be explained that the DER in 2017 was $56.1 \%$. In 2018 it decreased by $15.1 \%$ and in 2019 it increased by $22.8 \%$. Next will be analyzed the company's profitability ratio. The profitability ratio of PT. Polychem Indonesia Tbk is shown in the following table 5.

Table 5. GPM PT Polychem Indonesia Tbk 2017 - 2019 (expressed in USD)

\begin{tabular}{|c|c|c|c|}
\hline Ket & $\begin{array}{c}\text { Year } \\
2017\end{array}$ & 2018 & 2019 \\
\hline Gross Profit & 12.853 .309 & 14.593 .267 & -18.671 .871 \\
\hline Sales & 318.584 .810 & 356.636 .089 & 233.390 .689 \\
\hline GPM & $4,0 \%$ & $4,1 \%$ & $-8,0 \%$ \\
\hline
\end{tabular}

Source: www.idx.co.id

From the table above, it can be explained that the GPM in 2017 was $4.0 \%$. In 2018 it increased by $4.1 \%$ and in 2019 it decreased again, namely by $-8.0 \%$. Next will be analyzed the company's NPM. The NPM of PT. Polychem Indonesia Tbk is shown in the following table 6.

Table 6. NPM PT Polychem Indonesia Tbk 2017 - 2019 (expressed in USD)

Source: www.idx.co.id

From the table above, it can be explained that the NPM in 2017 was $-2.7 \%$. In 2018 it has increased by $-0.4 \%$ and in 2019 has decreased by $-12.7 \%$. Next will be analyzed the company's ROI. As for the ROI of PT. Polychem Indonesia Tbk is shown in the following table 7.

Table 7. ROI of PT Polychem Indonesia Tbk 2017 - 2019 (expressed in USD)

Source: www.idx.co.id

\begin{tabular}{|c|c|c|c|}
\hline \multirow[b]{2}{*}{ Explan } & \multicolumn{3}{|l|}{ Year } \\
\hline & 2017 & 2018 & 2019 \\
\hline Net Profit & -8.637 .865 & -1.304 .581 & -29.590 .834 \\
\hline Sales & 318.584 .810 & 356.636 .089 & 233.390 .689 \\
\hline NPM & $-2,7 \%$ & $-0,4 \%$ & $-12,7 \%$ \\
\hline
\end{tabular}

From the table above, it can be explained that the ROI in 2017 was $-2.3 \%$. In 2018 it increased by $0.5 \%$ and in 2019 it decreased again by $-11.6 \%$. Next will be analyzed the ROE of the company. As for the ROE of PT. Polychem Indonesia Tbk is shown in the following table 8.

Table 8. ROE of PT Polychem Indonesia Tbk 2017 - 2019 (expressed in USD)

\begin{tabular}{|c|c|c|c|}
\hline Explan & $\begin{array}{l}\text { Year } \\
2017\end{array}$ & 2018 & 2019 \\
\hline Net Profit & -8.637 .865 & -1.304 .581 & -29.590 .834 \\
\hline Total Assets & 374.110 .303 & 280.679 .854 & 255.228 .195 \\
\hline ROI & $-2,3 \%$ & $-0,5 \%$ & $-11,6 \%$ \\
\hline
\end{tabular}

Source: www.idx.co.id

From table 9 above, it can be explained that the ROE in 2017 was -3.6\%. In 2018 it increased by $0.5 \%$ and in 2019 it decreased again by $-14.2 \%$. 
Table 9. Financial Ratio Recapitulation PT Polychem Indonesia Tbk 2017-2019

\begin{tabular}{|c|c|c|c|c|c|}
\hline Financial Ratios & & 2017 & 2018 & 2019 & Average \\
\hline \multirow{2}{*}{ Liquidity Ratios } & $\mathrm{CR}$ & $215,2 \%$ & $469,3 \%$ & $325,0 \%$ & $336,5 \%$ \\
\hline & QR & $126,1 \%$ & $254,8 \%$ & $171,4 \%$ & $184,1 \%$ \\
\hline \multirow{2}{*}{ Solvency Ratios } & DR & $36,0 \%$ & $13,1 \%$ & $18,6 \%$ & $22,6 \%$ \\
\hline & DER & $56,1 \%$ & $15,1 \%$ & $22,8 \%$ & $31,3 \%$ \\
\hline \multirow{4}{*}{ Profitability Ratios } & GPM & $4,0 \%$ & $4,1 \%$ & $-8,0 \%$ & $0,0 \%$ \\
\hline & NPM & $-2,7 \%$ & $-0,4 \%$ & $-12,7 \%$ & $-5,3 \%$ \\
\hline & ROI & $-2,3 \%$ & $-0,5 \%$ & $-11,6 \%$ & $-4,8 \%$ \\
\hline & ROE & $-3,6 \%$ & $-0,5 \%$ & $-14,2 \%$ & $-6,1 \%$ \\
\hline
\end{tabular}

Based on the results of the financial ratio recapitulation table, it can be seen that the liquid-ty ratio at the average current ratio is $336.5 \%$. The standard current ratio is $200 \%$. Where this figure is very good for the company's ability to pay off its current debt. Meanwhile, the average quick ratio was $184.1 \%$. The standard Quick ratio is $150 \%$ where this figure is very good for meeting short-term obligations.

In the solvency ratio, it can be seen that the result of the average Debt Ratio (DR) is $22.6 \%$, which indicates that the company is in good condition. Because the standard Debt Ratio is $35 \%$. Where the figure is to measure the company's ability to pay the debt. While the average Debt Equity Ratio (DER) is $31.3 \%$, which indicates that the company is in good condition. Because the DER standard is $80 \%$ Where the figure is to measure the existing investment in the company.

In the Profitability Ratio, it can be seen that the results of the average Gross Profit Margin (GPM) are $0.0 \%$ which indicates that the company is in poor condition. Because the standard Gross Profit Margin is $30 \%$. Where the figure is to measure the efficiency of the cost of goods or production costs to generate gross profit. Meanwhile, the average net profit margin (NPM) is $-5.3 \%$, which indicates that the local company is in poor condition. Because the standard Net Profit Margin is 20\% (Cashmere, 2011). Where the figure is to measure the company's ability to generate net profits.

From the average Return on Investment (ROI), it is obtained at $-4.8 \%$, which indicates that the company is in unfavorable condition. Because the standard of Return on Investment is $30 \%$. Where the figure is to measures the percentage of profits obtained by the company. Meanwhile, the Return on Equity (ROE) is $-6.1 \%$ which indicates that the company is in poor condition. Because the standard of Return on Equity is $40 \%$. Where are the numbers for measure the ability of a company to generate Profits?

\section{Conclusion}

Based on the results of the above analysis, it can be concluded that:

1. The financial performance of PT Polychem Indonesia Tbk is seen from the liquidity ratio during the period 2017 to 2019 in good condition.

2. The financial performance of PT Polychem Indonesia Tbk is seen from the solvency ratio during the period 2017 to 2019 in good condition.

3. The financial performance of PT Polychem Indonesia Tbk, seen from the profitability ratio during the period 2017 to 2019 , was in poor condition.

The purpose of this study is to evaluate financial performance to meet the goals of the company so that the finance within the company can run well.

\section{Acknowledgment}

The writer expressed much gratitude to those involved who had already contributed to this journal

\section{References}

Alfaro, L., Chandra, A., Kalemli-Ozcan, S., \& Sayek, S. (2004). FDI and economic growth: The role of local financial markets. Journal of International Economics, 64(1), 89-112. 
Ali, N., \& Mingque, Y. (2018). Does foreign direct investment lead to economic growth? evidence from developing countries. International Journal of Economics and Finance, 10(3), 109-119.

Bank Indonesia. (2019). Retrieved from bi.go.id: http://www.bi.go.id/id/publikasi/laporan-tahunan/bi/pages/LKTBI-2018.aspx

Beck, T., Demirgeuc-Kunt, A., \& Levine, R. (2007). Finance, Inequality, and the Poor. Journal of Economic Growth, 12, 27-49.

Bettin, G., \& Zazzaro, A. (2011). Remittances and financial development: Substitutes or complements in economic growth. Bulletin of Economic Research, 64(4), 509-536.

Borensztein, E., De Gregorio, J., \& Lee, J. W. (1998). How does foreign direct investment affect economic growth. Journal of International Economics, 45(1), 115-135.

Burnside; C., \& David, D. (2000). Aid, policies, and growth. American Economic Review, 90(2000), 847-868.

Carment, D., \& Calleja, R. (2018). Diasporas and fragile states-beyond remittances assessing the theoretical and policy linkages. Journal of Ethnic and Migration Studies, 44(8), 1270-1288.

Chami, R., Fullenkamp, C., \& Jahjah, S. (2005). Are immigrant remittance flows a source of capital for development. IMF Staff Papers, 52(1), 55-81.

Chenery, H. B., \& Alan, M. S. (1966). Foreign assistance and economic development. American Economic Review, 52(2005), 55-81.

De Mello, R. (1999). Foreign direct investment led growth: Evidance from time series and panel data. Oxford Economics Papers, 51, 133-151.

Debass, T., \& Ardovino, M. (2009). Diaspora Direct Investment (DDI) : The untapped resource for development. United States: States Agency for International Development.

Giuliano , P., \& Ruiz-Arranz, M. (2009). Remittances, financial development, and growth. Journal of Development Economics, 90(1), 144152.

Intan, K. 2019. Merugi, PT Polychem Indonesia Tbk (ADMG) tidak bagikan dividen. Acces on November $20^{\text {th }} 2020$ at https://amp.kontan.co.id/news/merugi-pt-polychem-indonesia-tbk-admg-tidak-bagikan-dividen.

Issahaku, H., Abor, J. Y., \& Amidu, M. (2018). The effects of remittances on economic growth: reexamining the role of institutions. The Journal of Developing Areas, 52(4), 29-46.

Johnson, A. (2006). The effects of FDI inflows on host country economic growth. CESIS Electronic Working Paper Series. Paper (58).

Koinova, M. (2012). Autonomy and positionality in diaspora politics. International Political Sociology, 6(1), 99-103.

Koko, A. (2006). The home country effects of FDI in developed economies. European Institute of Japanese Studies', Stockholm School of Economics Working Paper(225).

Lipton, M. (1980). Migration from rural areas of poor countries: The impact on rural productivity and income distribution. World Development, $8(1), 1-24$.

Lumbila, \& Kevin, N. (2005). What makes FDI work? A panel anaysis of the growth effect of FDI in Africa. Wahington, DC: World Bank.

Lyroudi, Katerina, Jhon, P., \& Athanasious, V. (2004). Foreign direct investment and economic growth in transition economies. South-Eastern Europe Journal of Economics, 1, 97-110.

Mah, J. (2010). Foreign direct investment inflows and economic growth: The case of Korea. Review of Development Economics, 14, $275-304$.

Nwaogu, U. G., \& Ryan, M. J. (2015). FDI, foreign aid, remittance and economic growth in developing countries. Review of Development Economics, 19(1), 100-115.

World Bank. (2019). wdi.worldbank.org. Retrieved from http://databank.worldbank.org/data/ 